\title{
The Utility of DNA Barcoding for the Species Identification of Larval Fish in the Lower Ing River, Thailand
}

\author{
Dutrudi Panprommin ${ }^{1,2, *}$ (D), Kanyanat Soontornprasit ${ }^{1}$, Siriluck Tuncharoen ${ }^{1}$ \\ and Niti lamchuen ${ }^{3}$
}

\begin{abstract}
${ }^{1}$ School of Agriculture and Natural Resources, University of Phayao, Phayao 56000, Thailand.
${ }^{2}$ Center of Excellence on Agricultural Biotechnology (Ag-BIO/PERDO-CHE), Bangkok 10900, Thailand.

${ }^{3}$ School of Information and Communication Technology, University of Phayao, Phayao 56000, Thailand.
\end{abstract}

\section{Article History}

Received Mar 22,2019

Accepted Jun 10, 2020

First Online Jun 16, 2020

\section{Corresponding Author}

Tel.: +6654466666

E-mail: dutrudeep@yahoo.com

\section{Keywords}

Larval fish

Species identification

DNA barcoding

Cytochrome c oxidase I

Lower Ing River

\begin{abstract}
The species identification of larval fish is very important for sustainable fishery resource management. However, identification based on morphological characters is very difficult, complex and error-prone. DNA barcoding with the sequence of cytochrome $\mathrm{c}$ oxidase I (COI) gene was used to identify larval fish species from 10 stations in the tributaries of the lower Ing River. One hundred and six samples were collected between May 2016 and April 2017. The average length of the COI nucleotide sequences was approximately $640 \mathrm{bp}$. A total of 99 nucleotide sequences were identified in 35 species, 31 genera, 19 families and 9 orders, with $97-100 \%$ identity with entries in both the GenBank and BOLD databases. The genetic distance within species ranged from 0.000 to 0.004 . However, seven samples were identified at only the genus level because their sequences had not been reported in any databases. Based on IUCN conservation status, most species were classified as least concern (77.14\%). Approximately $69.23 \%$ of all species were related to human uses in fisheries, aquaculture or aquariums, whereas $30.77 \%$ of species were not assessed. Trichopsis vittata (family Osphronemidae) (90\%) had the most frequency of occurrence, followed by Oryzias minutillus (family Adrianichthyidae) (70\%) and Trichopodus trichopterus (family Osphronemidae) (70\%).
\end{abstract}

\section{Introduction}

The Ing River is a major water source of the Phayao and Chiang Rai provinces in northern Thailand and is a tributary of the Mekong River. It flows northwards from Kwan Phayao, Phayao Province through the Mekong River in Chiang Rai Province for approximately 240 kilometers. There are 86 fish species in the upper Mekong River at the Thai-Laos border, and 66 of these species migrate to lay eggs in its tributaries, such as the Ing River. The Ing River has a warmer water temperature and is a more suitable ecosystem for laying eggs than the cooler Mekong River, which flows from the Himalayas (Thai Baan Research, 2006). In addition, the Ing River also has a large variety of fish species that includes 82 fish species belonging to 57 genera and 22 families (Valunpion \& Suvarnaraksha, 2013). Therefore, the Ing River and its tributaries most likely contain the most diverse group of larval fish species.

The species identification of larval fish is very important for fishery resource management in various water sources for predicting the changes in fish populations and calculating the size of fish stocks (Termvidchakorn, 2003). However, the appearance of larval fish is completely different from that of adult fish. Also, species identification based on morphological characteristics, such as the numbers of muscles, the notochord and fin rays, body shape, and eye shape (Termvidchakorn, 2003) is uaually difficult. Moreover, the accuracy may be quite low; for example, a total of 
100 larval fish were identified based on morphology in five laboratories in Taiwan. The average accuracy was quite low: $80.1,41.1$ and $13.5 \%$ at the family, genus and species levels, respectively (Ko et al., 2013). A total of 354 larval fish samples were morphologically identified. Within these samples, $67.8 \%$ could be identified at the family level and $30 \%$ at the genus level, while the identification at the species level was not possible (Azmir, Esa, Amin, Yasin, \& Yusof, 2017).

DNA barcoding with the partial nucleotide sequence of the cytochrome c oxidase I (COI) gene serves as the core of a global bio-identification system for animals (Hebert, Cywinska, Ball, \& deWaard, 2003). All species can be differentiated by their $\mathrm{COI}$ sequences with a low average distance within species of $0.39 \%$ (Ward, Zemlak, Innes, Last, \& Hebert, 2005). In fish, DNA barcoding has been very successful for species identification because of the universal primers described by Ward et al. (2005) and Ivanova, Zemlak, Hanner, and Hebert (2007) that were very effective for the amplification of the COI sequences of most species. Furthermore, DNA barcoding was used for the identification of several larval fish species, including the members of Acanthuridae and Holocentridae families (Hubert, Delrieu-Trottin, Irisson, Meyer, \& Planes, 2010) and the genus Pseudoblennius (Kwun, 2018).

The objective of this study was to identify larval fish species collected from 10 stations in the tributaries of the lower Ing River using DNA barcoding. The samples were identified to obtain their scientific name after comparing their $\mathrm{COI}$ sequences with the reported sequences of organisms in databases. In addition, the human uses for and the distribution of each species were also determined. The results of this study would be useful for the creation of a database to manage fish resources in the future.

\section{Materials and Methods}

\section{Larval Fish Collection}

The larval fish were collected at 10 stations (Figure 1) in the tributaries of the lower Ing River in Chang Rai Province, northern Thailand between May 2016 and April 2017. The samples were obtained by using plastic nylon nets with $16 \times 16$ mesh/inch that were $3 \times 1.2 \times 1.2 \mathrm{~m}$ in size. The nets were towed many times close to marginal areas to obtain the most samples. All samples were anesthetized in $0.2 \mathrm{~g} / \mathrm{L}$ of MS-222 (Sigma, Missouri, USA) dissolved in water, preserved in absolute ethanol and transported to the laboratory. Samples with similar morphological characteristics were grouped together under a stereo microscope and photographed.

\section{DNA Barcoding}

A total of 106 genomic DNA samples from representative larval fish were extracted from muscle

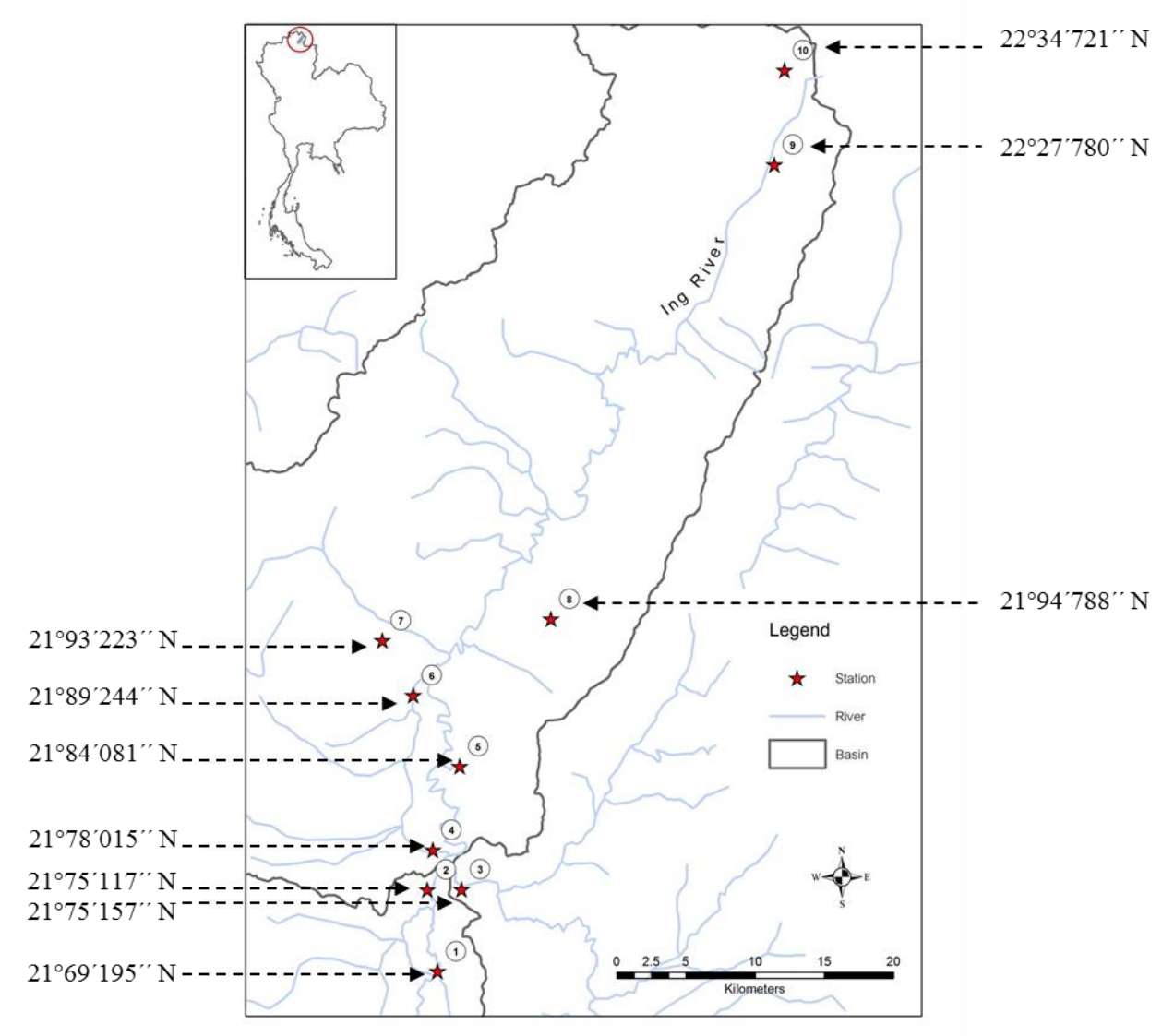

Figure 1. Collection stations in the tributaries of the lower Ing River, northern Thailand. 
tissues using proteinase $\mathrm{K}$ digestion followed by the standard phenol chloroform method (Sambrook \& Russell, 2001). The quality of the extracted DNA was determined on a $1 \%$ agarose gel. The fragments of the $\mathrm{COI}$ gene were amplified with four primers (FishF1, FishF2, FishR1, and FishR2) that were described by Ward et al. (2005) using PCR. A total volume of $25 \mu \mathrm{l}$ of a PCR mixture contained $1 \times$ Taq buffer, $2.5 \mathrm{mM} \mathrm{MgCl}_{2}, 0.4 \mu \mathrm{M}$ of each primer, $1 \mu \mathrm{M}$ dNTPs, $0.625 \mathrm{U}$ of Taq DNA polymerase (RBC Bioscience Corp., New Taipei, Taiwan) and 50-100 ng of the extracted DNA. The thermal conditions included initial denaturation for $2 \mathrm{~min}$ at $95^{\circ} \mathrm{C}$ followed by 35 cycles of denaturation for $30 \mathrm{sec}$ at $94^{\circ} \mathrm{C}$, annealing for $30 \mathrm{sec}$ at $54^{\circ} \mathrm{C}$, extension for $1 \mathrm{~min}$ at $72^{\circ} \mathrm{C}$ and an extension for $10 \mathrm{~min}$ at $72^{\circ} \mathrm{C}$. The PCR products were visualized by $1 \%$ agarose gel electrophoresis under UV light.

The amplified PCR products were purified with the HiYield $^{\text {TM }}$ Gel/PCR DNA Fragments Extraction kit (RBC Bioscience) according to the manufacturer's instructions. All purified PCR products were sequenced in one direction with the FishF1/FishF2 primers complementary to the $5^{\prime}$ ends of the COI gene fragments by Macrogen Inc. in South Korea.

\section{Species Identification}

All sequences were searched for open reading frames using ORF finder program (https://www.ncbi.nlm.nih.gov/orffinder/). The scientific name of each sample was obtained by comparing its $\mathrm{COI}$ sequence with reference sequences in the GenBank (https://www.ncbi.nlm.nih.gov/) database using the BLASTn program (Altschul, Gish, Miller, Myers, \& Lipman, 1990) and the BOLD database (http://www.boldsystems.org/). Sequence similarity greater than $97 \%$ was the criterion for identification at the species level (Wong \& Hanner, 2008) and a similarity lower than that was used for identification at the genus level. All COI sequences with similarities less than $97 \%$ were aligned together using the ClustalW program (Thompson, Higgins, \& Gibson, 1994). The similar sequences were considered the same genus. Furthermore, the ClustalW program was also used to align the $\mathrm{COI}$ sequences of each species to determine the existing haplotypes. The genetic distances within each species were calculated with the Kimura 2parameter (K2P) model in MEGA version 4.0 (Tamura, Dudley, Nei, \& Kumar, 2007). All sequences were deposited in the GenBank database.

\section{Larval Fish Diversity}

From the comparison of the $\mathrm{COI}$ sequences to databases, the fish species were classified based on the fish taxonomy of Nelson, Grande, and Wilson (2016). The conservation status of each fish species was determined on the IUCN webpage (https://www.iucnredlist.org/). In addition, the human uses for each fish were determined with the FishBase webpage (http://www.fishbase.org/). The frequency of occurrence $(\mathrm{V}, \%)$ of each species was calculated according to Joganzen \& Faizova (1978) and Čivas \& Kesminas (2011).

\section{Results}

\section{DNA Barcoding for Species Identification}

A total of 106 nucleotide sequences were successfully amplified using four primers. No deletion, insertion or stop codon was observed in any of the sequences after trimming. The average length of the amplified COI genes was $640 \mathrm{bp}$ and ranged from 627 to $648 \mathrm{bp}$. From the comparison with reference sequences in the GenBank and BOLD databases, 99 COI gene sequences were classified into 9 orders, 19 families, 31 genera and 35 species with $97-100 \%$ identity (Table 1 , 2). However, 7 samples could not be identified at the species level and could be classified only at the genus level, including Danio sp. (1 sample), Opsarius sp. (1 sample), Brachygobius sp. (3 samples) and Dentex sp. (2 samples), which were $84-93 \%$ identity and had no match in the GenBank and BOLD databases, respectively (Table 2).

The existing haplotypes of each species ranged from 1 to 3 . The genetic distance within species ranged from 0.000 to 0.004 . The $106 \mathrm{COI}$ sequences were deposited in the GenBank database under the accession number MK628319-MK628424 (Table 2).

\section{Larval Fish Diversity}

The order Cypriniformes was the most dominant taxon among fish found in the tributaries of the lower Ing River and contained the highest percentage of fish, $38.46 \%$ (Figure 2). The second most populated taxon was the order Anabantiformes (17.95\%), followed by the orders Siluriformes and Gobiiformes (10.26\%), Synbranchiformes, Cyprinodontiformes and Beloniformes (5.13\%). The three orders Cichliformes, Spariformes, and Osteoglossiformes contained the lowest percentage of fish (2.56\%).

A total of 35 species were classified by their IUCN status as a species of least concern (27 species, $77.14 \%$ ), followed by not evaluated species ( 7 species, $20.00 \%$ ) and data deficient species (1 species, 2.86\%) (Table 1).

In terms of the human uses for larval fish species as determined by FishBase, several larval fish species were used for many purposes, including fisheries, aquaculture or aquariums (Table 1 ). There were only 8 larval fish species (20.51\%), such as Notopterus notopterus, Barbonymus gonionotus, and Hemibagrus nemurus, that were used for all purposes. Only two purposes and one purpose were identified for 10 (25.64\%) and 9 (23.08\%) species, respectively. The 


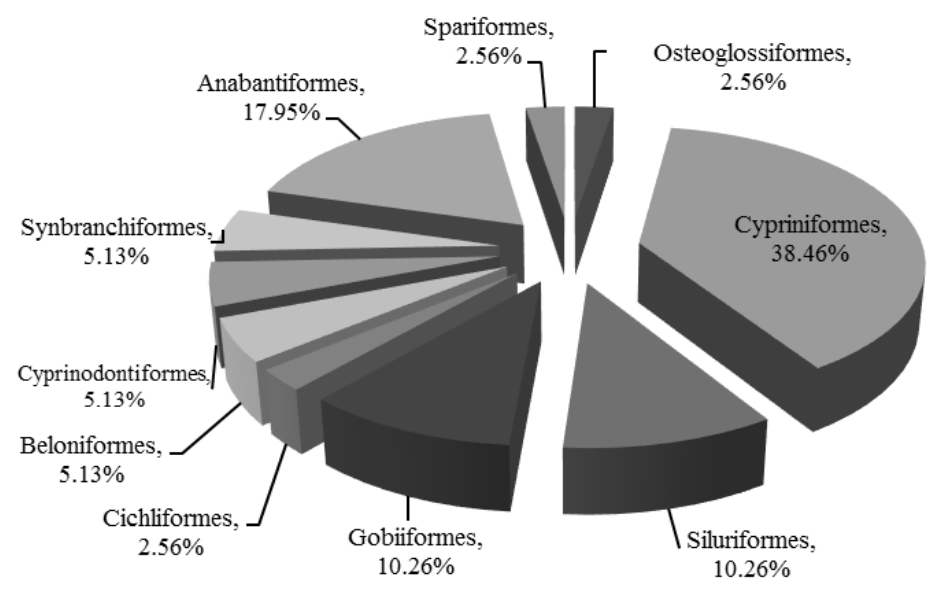

Figure 2. The percentage of larval fish species collected from the tributaries of the lower Ing River comprising different orders.

human uses for the remaining species (30.77\%) could not be assigned by the database.

Of the 10 different stations sampled, stations 5 and 7 had the most larval fish species, followed by stations 1, 6 and 4 (Table 3). The fewest species were found at stations 3 and 10 . Furthermore, the most frequently found larval fish was Trichopsis vittata (90\%), followed by Oryzias minutillus (70\%) and Trichopodus trichopterus (70\%) (Table 3).

\section{Discussion}

Because the morphological characteristics of larval fish are completely different from those of adult fish, the species identification of these larval fish is very difficult, especially for nontaxonomic experts. Currently, DNA barcoding is a popular tool for identifying the species of organisms. DNA barcoding can efficiently identify larval fish from several water sources, including the eastern

Table 1. Classification of larval fish species in the tributaries of the lower Ing River, their IUCN statuses and their human uses

\begin{tabular}{|c|c|c|c|c|c|c|}
\hline Order & Family & Genus & Species & $\begin{array}{l}\text { No. of } \\
\text { samples }\end{array}$ & $\begin{array}{l}\text { IUCN } \\
\text { status }\end{array}$ & Human uses \\
\hline Osteoglossiformes & Notopteridae & Notopterus & N. notopterus & 1 & LC & Fisheries, Aquaculture, Aquariums \\
\hline \multirow[t]{15}{*}{ Cypriniformes } & \multirow[t]{14}{*}{ Cyprinidae } & Amblypharyngodon & $\begin{array}{l}\text { A. } \\
\text { chulabhornae }\end{array}$ & 2 & LC & NA \\
\hline & & Barbonymus & B. gonionotus & 8 & LC & Fisheries, Aquaculture, Aquariums \\
\hline & & Cyclocheilichthys & C. armatus & 1 & $\mathrm{LC}$ & NA \\
\hline & & \multirow[t]{2}{*}{ Danio } & D. roseus & 5 & $\mathrm{LC}$ & NA \\
\hline & & & Danio sp. & 1 & NA & NA \\
\hline & & Esomus & E. metallicus & 14 & $\mathrm{LC}$ & Fisheries \\
\hline & & Henicorhynchus & H. siamensis & 3 & LC & Fisheries, Aquariums \\
\hline & & Labiobarbus & L. siamensis & 3 & LC & Fisheries \\
\hline & & Opsarius & Opsarius sp. & 1 & NA & NA \\
\hline & & Puntigrus & $\begin{array}{l}P . \\
\text { partipentazona }\end{array}$ & 3 & LC & Aquariums \\
\hline & & \multirow[t]{2}{*}{ Puntius } & P. cf. sophore & 4 & LC & Aquariums \\
\hline & & & P. brevis & 1 & LC & NA \\
\hline & & Rasbora & $\begin{array}{l}R . \\
\text { borapetensis }\end{array}$ & 3 & LC & Aquariums \\
\hline & & Systomus & S. orphoides & 2 & $\mathrm{NE}$ & NA \\
\hline & Cobitidae & Pangio & P. anguillaris & 1 & $\mathrm{NE}$ & Aquariums \\
\hline \multirow[t]{4}{*}{ Siluriformes } & \multirow[t]{2}{*}{ Loricariidae } & \multirow[t]{2}{*}{ Pterygoplichthy } & P. anisitsi & 1 & $\mathrm{NE}$ & Fisheries, Aquariums \\
\hline & & & P. pardalis & 2 & $\mathrm{NE}$ & Fisheries, Aquariums \\
\hline & Bagridae & Hemibagrus & H. nemurus & 3 & LC & Fisheries, Aquaculture, Aquariums \\
\hline & Clariidae & Clarias & C. batrachus & 1 & LC & Fisheries, Aquaculture, Aquariums \\
\hline \multirow[t]{4}{*}{ Gobiiformes } & Eleotridae & Oxyeleotris & O. marmorata & 1 & LC & Fisheries, Aquaculture, Aquariums \\
\hline & \multirow[t]{2}{*}{ Gobiidae } & Brachygobius & $\begin{array}{l}\text { Brachygobius } \\
\text { sp. }\end{array}$ & 3 & NA & 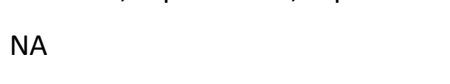 \\
\hline & & Gobiopterus & G. lacustris & 3 & $\mathrm{NE}$ & NA \\
\hline & Ambassidae & Parambassis & P. ranga & 2 & $\mathrm{LC}$ & Fisheries, Aquariums \\
\hline Cichliformes & Cichlidae & Oreochromis & O. niloticus & 5 & $\mathrm{LC}$ & Fisheries, Aquaculture \\
\hline
\end{tabular}


Table 1. Continued

\begin{tabular}{|c|c|c|c|c|c|c|}
\hline Order & Family & Genus & Species & $\begin{array}{l}\text { No. of } \\
\text { samples }\end{array}$ & $\begin{array}{l}\text { IUCN } \\
\text { status }\end{array}$ & Human uses \\
\hline \multirow[t]{2}{*}{ Beloniformes } & Adrianichthyidae & Oryzias & $\begin{array}{l}O . \\
\text { minutillus }\end{array}$ & 3 & LC & NA \\
\hline & Zenarchopteridae & Dermogenys & D. pusilla & 4 & NE & Fisheries, Aquariums \\
\hline \multirow[t]{2}{*}{ Cyprinodontiformes } & Poeciliidae & Gambusia & G. affinis & 3 & LC & Fisheries, Aquariums \\
\hline & & Poecilia & P. reticulata & 3 & NE & Fisheries, Aquariums \\
\hline \multirow[t]{2}{*}{ Synbranchiformes } & Synbranchidae & Monopterus & $\begin{array}{l}\text { M. } \\
\text { javanensis }\end{array}$ & 1 & LC & Fisheries, Aquaculture, Aquariums \\
\hline & Mastacembelidae & Mastacembelus & M. favus & 3 & LC & NA \\
\hline \multirow[t]{7}{*}{ Anabantiformes } & Anabantidae & Anabas & $\begin{array}{l}\text { A. } \\
\text { testudineus }\end{array}$ & 1 & DD & Fisheries, Aquaculture, Aquariums \\
\hline & Osphronemidae & Trichopodus & $\begin{array}{l}T . \\
\text { microlepis }\end{array}$ & 4 & LC & Fisheries, Aquariums \\
\hline & & & $\begin{array}{l}T . \\
\text { trichopterus }\end{array}$ & 2 & LC & Fisheries, Aquaculture, Aquariums \\
\hline & & Trichopsis & T. vittata & 2 & LC & Aquariums \\
\hline & Channidae & Channa & C. gachua & 1 & LC & Aquariums \\
\hline & & & C. striata & 2 & $\mathrm{LC}$ & Fisheries, Aquaculture, Aquariums \\
\hline & Pristolepididae & Pristolepis & P. fasciata & 1 & $\mathrm{LC}$ & Fisheries, Aquariums \\
\hline Spariformes & Sparidae & Dentex & Dentex sp. & 2 & NA & NA \\
\hline
\end{tabular}

LC: Least concern, DD: Data deficient, NE: Not evaluated and NA: Not assessed

Atlantic Ocean (Ardura, Morote, Kochzius, \& GarciaVazquez, 2016), Bahia, northeastern Brazil (Brandão et al., 2016) and the mangroves of peninsular Malaysia (Azmir et al., 2017), at the species level. Moreover, the accuracy of species-level identification with DNA barcoding was higher than that with the morphological method (Overdyk, Holm, Crawford, \& Hanner, 2016; Azmir et al., 2017).

A total of 99 samples were identified as 35 species with more than $97 \%$ similarity based on the general rule of Wong and Hanner (2008). However, if the similarity was less than $96 \%$, it would be considered at the genus level (Chen et al., 2013). Seven samples were identified at only the genus level because the similarities were between $84-93 \%$ and the COI nucleotide sequences of the relevant species have not been reported in any databases. Thus, increasing the number of $\mathrm{COI}$ nucleotide sequences in databases will be important and useful for identifying unknown fish species (Sarma \& Mankodi, 2017).

The average length of the $106 \mathrm{COI}$ sequences was $640 \mathrm{bp}$, which was shorter than that reported in other studies such as Ward et al. (2005), Pegg, Sinclair, Briskey, and Aspden (2006) and Brandão et al. (2016). Although the amplified $\mathrm{COI}$ sequences were bidirectionally sequenced using both forward and reverse primers in these studies, the 106 sequences in the current study were sequenced only in the forward direction. However, 130 bp mini-barcodes successfully identified several organisms at the species level (Meusnier et al., 2008). One to three haplotypes were found as well as a low genetic distance within species that ranged from 0.000 to 0.004 (0-0.4\%) was observed for each species. All species were differentiated by their COI sequence with a $0.39 \%$ distance (Ward et al., 2005).
This study indicated that DNA barcoding is an effective approach to identify larval fish species in the tributaries of the lower Ing River.

Most larval fish species found in the tributaries of the lower Ing River belonged to the order Cypriniformes, which is the most diverse order in Southeast Asia (Nelson et al., 2016). Regarding their IUCN conservation status, the majority of fish species were classified as a species of least concern (77.14\%), which is similar to the findings of previous studies that identified $72 \%$ (Joadder, Galib, Haque, \& Chaki, 2015) and 59\% (Pramanik, Hasan, Bisshas, Hossain, \& Biswas, 2017) of species to be species of least concern in the Padma and Meghna Rivers in Bangladesh, respectively.

Several larval fish species are used in fisheries, aquaculture or aquariums in the adult stage. However, some fish are alien aquatic species in Thailand, although FishBase assessed the human uses of some of these species, such as Pterygoplichthys pardalis, P. anisitsi and Oreochromis niloticus (Termvidchakorn, Vidthayanon, Getpetch, Sorrak, \& Paradonpanichakul, 2003). Members of the genus Pterygoplichthys are invasive alien species that affect native species through egg predation, especially P. pardalis (Chaichana \& Jongphadungkiet, 2012). In addition, $O$. niloticus is a noninvasive species that successfully adapts to and is widely distributed in various aquatic habitats. However, environmental change may cause this species to grow faster than native fish and interrupt the recovery of ecological balance (Termvidchakorn et al., 2003).

In general, the frequency of occurrence is an index that indicates the ability of a species to live or spread in different environments (Keawkhiew, Keawtip, Seetakoses, \& Montien-art, 2013). The most common species was Trichopsis vittata, followed by Trichopodus 
Table 2. Larval fish species identification in the GenBank and BOLD databases, length of COI sequences, accession no., no. of haplotypes and genetic distances within each species

\begin{tabular}{|c|c|c|c|c|c|c|c|c|c|}
\hline \multirow[b]{2}{*}{ No. } & \multicolumn{2}{|l|}{ GenBank } & \multicolumn{2}{|l|}{ BOLD } & \multirow[b]{2}{*}{ Identified species } & \multirow{2}{*}{$\begin{array}{l}\text { Length } \\
\text { of COI } \\
\text { gene } \\
\text { (bp) }\end{array}$} & \multirow[b]{2}{*}{ Accession no. } & \multirow[b]{2}{*}{$\begin{array}{c}\text { No. of } \\
\text { haplotypes }\end{array}$} & \multirow[b]{2}{*}{$\begin{array}{l}\text { Genetic } \\
\text { distance }\end{array}$} \\
\hline & Species & \%Identity & Species & \%Identity & & & & & \\
\hline 1 & Notopterus notopterus & 99 & Notopterus notopterus & 99.68 & N. notopterus & 630 & MK628319 & 1 & - \\
\hline 2 & Amblypharyngodon chulabhornae & 99 & Amblypharyngodon chulabhornae & 99.68 & A. chulabhornae & 636 & MK628320-MK628321 & 1 & 0.000 \\
\hline 3 & Barbonymus gonionotus & 99 & Barbonymus gonionotus & $99.63-100$ & B. gonionotus & 648 & MK628322-MK628329 & 3 & 0.003 \\
\hline 4 & Cyclocheilichthys armatus & 99 & Cyclocheilichthys armatus & 99.51 & C. armatus & 630 & MK628330 & 1 & _ \\
\hline 5 & Danio roseus & 99 & Danio roseus & 100 & D. roseus & 636 & MK628331-MK628335 & 1 & $0 . \overline{0} 00$ \\
\hline 6 & Danio roseus & 93 & No match & _ & Danio sp. & 630 & MK628336 & 1 & _ \\
\hline 7 & Esomus metallicus & 99 & Esomus metallicus & $99.22-99.38$ & E. metallicus & 648 & MK628337-MK628350 & 3 & $0 . \overline{0} 01$ \\
\hline 8 & Henicorhynchus siamensis & 99 & Henicorhynchus siamensis & 99.84 & H. siamensis & 630 & MK628351-MK628353 & 1 & 0.000 \\
\hline 9 & Labiobarbus siamensis & 99 & Labiobarbus siamensis & 99.02 & L. siamensis & 630 & MK628354-MK628356 & 1 & 0.000 \\
\hline 10 & Opsarius koratensis & 90 & No match & _- & Opsarius sp. & 630 & MK628357 & 1 & _- \\
\hline 11 & Puntigrus partipentazona & 99 & Puntigrus partipentazona & 99.02 & P. partipentazona & 642 & MK628358-МK628360 & 1 & $0 . \overline{000}$ \\
\hline 12 & Puntius cf. sophore & 99 & Puntius cf. sophore & 100 & P. cf. sophore & 648 & MK628361-MK628364 & 1 & 0.000 \\
\hline 13 & Puntius brevis & 99 & Puntius brevis & 99.17 & P. brevis & 639 & MK628365 & 1 & _- \\
\hline 14 & Rasbora borapetensis & 99 & Rasbora borapetensis & $99.68-99.84$ & R. borapetensis & 636 & MK628366-МK628368 & 2 & $0 . \overline{00} 01$ \\
\hline 15 & Systomus orphoides & 100 & Systomus orphoides & 100 & S. orphoides & 633 & MK628369-MK628370 & 1 & 0.000 \\
\hline 16 & Pangio anguillaris & 97 & Pangio anguillaris & 97 & P. anguillaris & 636 & MK628371 & 1 & _- \\
\hline 17 & Pterygoplichthys anisitsi & 99 & Pterygoplichthys anisitsi & 100 & P. anisitsi & 642 & MK628372 & 1 & - \\
\hline 18 & Pterygoplichthys pardalis & 99 & Pterygoplichthys pardalis & $99.84-100$ & P. pardalis & 642 & MK628373-МK628374 & 2 & $0 . \overline{00} 2$ \\
\hline 19 & Hemibagrus nemurus & 99 & Hemibagrus nemurus & $99.52-99.68$ & H. nemurus & 648 & MK628375-MK628377 & 2 & 0.001 \\
\hline 20 & Clarias batrachus & 99 & Clarias batrachus & 100 & C. batrachus & 636 & MK628378 & 1 & _- \\
\hline 21 & Oxyeleotris marmorata & 100 & Oxyeleotris marmorata & 99.68 & O. marmorata & 633 & MK628379 & 1 & - \\
\hline 22 & Brachygobius kabiliensis & $87-88$ & No match & 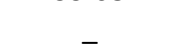 & Brachygobius sp. & 636 & MK628380-MK628382 & 2 & $0 . \overline{004}$ \\
\hline 23 & Gobiopterus lacustris & $99-100$ & Gobiopterus lacustris & $99.6 \overline{8}-100$ & G. lacustris & 636 & MK628383-МK628385 & 2 & 0.002 \\
\hline 24 & Parambassis ranga & 98 & Parambassis ranga & $98.05-98.21$ & P. ranga & 639 & MK628386-MK628387 & 2 & 0.002 \\
\hline 25 & Oreochromis niloticus & 100 & Oreochromis niloticus & 100 & O. niloticus & 639 & MK628388-MK628392 & 1 & 0.000 \\
\hline 26 & Oryzias minutillus & 99 & Oryzias minutillus & 99.06 & O. minutillus & 639 & МK628393-МK628395 & 2 & 0.002 \\
\hline 27 & Dermogenys pusilla & 99 & Dermogenys pusilla & 100 & D. pusilla & 642 & MK628396-MK628399 & 1 & 0.000 \\
\hline 28 & Gambusia affinis & 100 & Gambusia affinis & 100 & G. affinis & 648 & MK628400-MK628402 & 1 & 0.000 \\
\hline 29 & Poecilia reticulata & 99 & Poecilia reticulata & 100 & P. reticulata & 639 & MK628403-MK628405 & 2 & 0.003 \\
\hline 30 & Monopterus javanensis & 99 & Monopterus javanensis & 98.53 & M. javanensis & 630 & MK628406 & 1 & 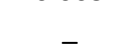 \\
\hline 31 & Mastacembelus favus & 100 & Mastacembelus favus & 100 & M. favus & 639 & MK628407-МK628409 & 1 & $0 . \overline{0} 00$ \\
\hline 32 & Anabas testudineus & 100 & Anabas testudineus & 100 & A. testudineus & 639 & MK628410 & 1 & _ \\
\hline 33 & Trichopodus microlepis & 100 & Trichopodus microlepis & 100 & T. microlepis & 648 & MK628411-MK628414 & 1 & $0 . \overline{000}$ \\
\hline 34 & Trichopodus trichopterus & 100 & Trichopodus trichopterus & 100 & T. trichopterus & 633 & MK628415-MK628416 & 1 & 0.000 \\
\hline 35 & Trichopsis vittata & 100 & Trichopsis vittata & 100 & T. vittata & 636 & MK628417-MK628418 & 1 & 0.000 \\
\hline 36 & Channa gachua & 99 & Channa gachua & 99.84 & C. gachua & 639 & MK628419 & 1 & - \\
\hline 37 & Channa striata & 99 & Channa striata & 99.68 & C. striata & 642 & MK628420-MK628421 & 1 & $0 . \overline{000}$ \\
\hline 38 & Pristolepis fasciata & 100 & Pristolepis fasciata & 99.34 & P. fasciata & 627 & MK628422 & 1 & - \\
\hline 39 & Dentex tumifrons & 84 & No match & & Dentex sp. & 636 & MK628423-MK628424 & 2 & $0 . \overline{003}$ \\
\hline
\end{tabular}


Table 3. Distribution and frequency $(\mathrm{V}, \%)$ of occurrence of larval fish species in 10 different stations from the tributaries of the lower Ing River

\begin{tabular}{|c|c|c|c|c|c|c|c|c|c|c|c|}
\hline \multirow{2}{*}{ Species } & \multicolumn{10}{|c|}{ Stations } & \multirow{2}{*}{$\mathrm{V}, \%$} \\
\hline & 1 & 2 & 3 & 4 & 5 & 6 & 7 & 8 & 9 & 10 & \\
\hline Notopterus notopterus & - & - & - & - & - & + & - & - & - & - & 10 \\
\hline Amblypharyngodon chulabhornae & + & - & - & - & + & - & + & - & - & - & 30 \\
\hline Barbonymus gonionotus & + & - & - & - & + & + & + & + & - & - & 50 \\
\hline Cyclocheilichthys armatus & - & - & - & - & + & - & - & - & - & - & 10 \\
\hline Danio roseus & - & - & - & + & + & - & + & + & + & + & 60 \\
\hline Danio sp. & - & - & - & - & - & - & - & - & + & - & 10 \\
\hline Esomus metallicus & + & - & - & + & + & - & + & + & + & - & 60 \\
\hline Henicorhynchus siamensis & - & + & - & - & - & - & + & - & - & - & 20 \\
\hline Labiobarbus siamensis & + & + & - & - & + & + & - & - & - & - & 40 \\
\hline Opsarius sp. & - & - & + & - & - & - & - & - & - & - & 10 \\
\hline Puntigrus partipentazona & - & - & + & - & - & + & - & - & - & - & 20 \\
\hline Puntius cf. sophore & - & + & - & - & + & - & - & + & + & - & 40 \\
\hline Puntius brevis & + & - & - & - & - & - & - & - & - & - & 10 \\
\hline Rasbora borapetensis & + & + & + & + & - & + & - & - & - & + & 60 \\
\hline Systomus orphoides & - & - & - & - & - & - & - & - & + & - & 10 \\
\hline Pangio anguillaris & + & - & - & - & - & - & - & - & - & - & 10 \\
\hline Pterygoplichthys anisitsi & - & - & - & + & - & - & - & - & - & - & 10 \\
\hline Pterygoplichthys pardalis & - & - & - & - & - & - & + & - & - & - & 10 \\
\hline Hemibagrus nemurus & - & - & - & - & + & - & + & - & - & - & 20 \\
\hline Clarias batrachus & - & - & - & - & - & - & + & - & - & - & 10 \\
\hline Oxyeleotris marmorata & + & + & + & - & - & - & + & - & - & - & 40 \\
\hline Brachygobius sp. & + & - & - & - & + & + & + & - & - & - & 40 \\
\hline Gobiopterus lacustris & + & + & - & + & + & + & - & - & - & + & 60 \\
\hline Parambassis ranga & + & - & + & - & + & + & + & - & - & - & 50 \\
\hline Oreochromis niloticus & - & + & - & + & - & + & + & + & - & - & 50 \\
\hline Oryzias minutillus & - & - & - & + & + & + & + & + & + & + & 70 \\
\hline Dermogenys pusilla & + & + & - & + & - & - & - & - & - & + & 40 \\
\hline Gambusia affinis & - & - & - & + & - & - & - & + & + & - & 30 \\
\hline Poecilia reticulate & - & - & - & - & - & - & - & + & - & - & 10 \\
\hline Monopterus javanensis & - & - & - & - & - & - & - & + & - & - & 10 \\
\hline Mastacembelus favus & - & - & - & - & - & + & + & - & - & - & 20 \\
\hline Anabas testudineus & - & - & - & - & + & - & - & - & - & - & 10 \\
\hline Trichopodus microlepis & + & - & - & + & + & - & - & - & - & - & 30 \\
\hline Trichopodus trichopterus & + & + & - & + & + & - & + & + & + & - & 70 \\
\hline Trichopsis vittata & + & + & + & + & + & + & + & - & + & + & 90 \\
\hline Channa gachua & - & - & - & - & - & - & - & + & - & - & 10 \\
\hline Channa striata & + & + & - & + & - & + & + & + & - & - & 60 \\
\hline Pristolepis fasciata & - & - & + & - & - & + & - & - & - & - & 20 \\
\hline Dentex sp. & - & - & - & - & + & + & - & - & - & - & 20 \\
\hline Total species & 16 & 11 & 7 & 13 & 17 & 15 & 17 & 12 & 9 & 6 & \\
\hline
\end{tabular}

+ Found, - Missed

trichopterus, which can survive in oxygen-poor water because these species have an accessory air-breathing organ called the labyrinth that allows them to directly breathe the air from the surface of the water (Suvarnaraksha, 2015). Thus, these species were widely found in various water sources, even in polluted water. Moreover, Oryzias minutillus was also widely observed in many stations, and this species can live in a variety of habitats, such as shallow ponds, ditches and paddy fields (Ngamniyom, 2012). Because the station 3, 9 and 10 are shollow and narrow streams, less fish species were found. However, most larval fish species were found at station 5 because this station is near the Ing River in the Thoeng District, Chiang Rai Province, where is a wide stream and has water all year round. In addition, most adult fish species were collected in that area (Valunpion
\& Suvarnaraksha, 2013). This result indicated that this area is suitable to lay eggs and serve as a nursery for the fish.

\section{Conclusion}

DNA barcoding is an efficient approach for identifying larval fish collected from 10 stations in the tributaries of the lower Ing River. This method successfully identified $93.4 \%$ of 106 samples at the species level, whereas 7 samples (6.6\%) were identified at only the genus level. These results of this study will be used for a DNA barcode database to plan the designation of conservation areas for spawning and the nursing of fish for sustainable fishery resource management in the future. 


\section{Acknowledgements}

This research was funded by the grant (number RD59022 and UoE58004), Unit of Excellence 2019 on Biodiversity and Natural Resources Management (number UoE62005) from the University of Phayao and was partially supported by the Center of Excellence on Agricultural Biotechnology, Science and Technology Postgraduate Education and Research Development Office, Office of Higher Education Commission, Ministry of Education (AG-BIO/PERDO-CHE). We also thank the Central Laboratory University of Phayao for laboratory facilities.

\section{References}

Altschul, S.F., Gish, W., Miller, W., Myers, E.W., \& Lipman, D.J. (1990). Basic local alignment search tool. Journal of Molecular Biology, 215(3), 403-410. https://doi.org/10.1016/S0022-2836(05)80360-2

Ardura, A., Morote, E., Kochzius, M., \& Garcia-Vazquez, E. (2016). Diversity of planktonic fish larvae along a latitudinal gradient in the Eastern Atlantic Ocean estimated through DNA barcodes. PeerJ, 4, e2438. https://doi.org/10.7717/peerj.2438

Azmir, I.A., Esa, Y., Amin, S.M.N., Yasin, I.S.M., \& Yusof, F.Z.M. (2017). Identification of larval fish in mangrove areas of Peninsular Malaysia using morphology and DNA barcoding methods. Journal of Applied Ichthyology, 33(5), 998-1006. https://doi.org/10.1111/jai.13425

Brandão, J.H.S.G., Bitencourt, J.A., Santos, F.B., Watanabe, L.A., Schneider, H., Sampaio, I., \& Affonso, P.R.A.M. (2016). DNA barcoding of coastal ichthyofauna from Bahia, northeastern Brazil, South Atlantic: high efficiency for systematics and identification of cryptic diversity. Biochemical Systematics and Ecology, 65, 214-224. https://doi.org/10.1016/j.bse.2016.02.012

Chaichana, R., \& Jongphadungkiet, S. (2012). Assessment of the invasive catfish Pterygoplichthys pardalis (Castelnau, 1855) in Thailand: ecological impacts and biological control alternatives. Tropical Zoology, 25(4), 173-182. https://doi.org/10.1080/03946975.2012.738494

Chen, I.S., Shao, K.T., Hsu, S.L., Gong, G.C., Chen, Y.C., \& Liu, T.K. (2013). DNA barcoding of coastal larval fish communities of Dongsha Island, south China sea revealed by mitochondrial $\mathrm{CO}$ I sequences. Journal of Marine Science and Technology (Taiwan), 21(SUPPL), 252-257. https://doi.org/10.6119/JMST-013-1223-3

Čivas, L., \& Kesminas, V. (2011). Fish distribution and ecological state of the Siesartis River, Lithuania. Acta Zoologica Lituanica, 21(2), 153-162. https://doi.org/10.2478/v10043-011-0018-y

Hebert, P.D.N., Cywinska, A., Ball, S.L., \& deWaard, J.R. (2003). Biological identifications through DNA barcodes. Proceedings of the Royal Society of London. Series B, 270, 313-321. https://doi.org/10.1098/rspb.2002.2218

Hubert, N., Delrieu-Trottin, E., Irisson, J.-O., Meyer, C., \& Planes, S. (2010). Identifying coral reef fish larvae through DNA barcoding: a test case with the families Acanthuridae and Holocentridae. Molecular Phylogenetics and Evolution, 55(3), 1195-1203. https://doi.org/10.1016/j.ympev.2010.02.023
Ivanova, N.V., Zemlak, T.S., Hanner, R.H., \& Hebert, P.D.N. (2007). Universal primer cocktails for fish DNA barcoding. Molecular Ecology Notes, 7(4), 544-548. https://doi.org/10.1111/j.1471-8286.2007.01748.x

Joadder, M.A.R., Galib, S.M., Haque, S.M.M., \& Chaki, N. (2015). Fishes of the river Padma, Bangladesh: current trend and conservation status. Journal of Fisheries, 3(2), 259-266.

http://dx.doi.org/10.17017/jfish.v3i2.2015.111

Joganzen, V.G., \& Faizova, L.V. (1978). On the determination of indices of occurrence, abundance and biomass and their interrelations in some hydrobionts. Elements of aquatic ecosystems, Moscow, 215-225.

Keawkhiew, P., Keawtip, S., Seetakoses, P., \& Montien-art, B. (2013). Biodiversity of fish in Maesaw Creek at the Intiative Highland Agricultural Development Station Project, Ban Santisuk, Khunkual subdistrict, Phong district, Phayao province. Journal of Fisheries Technology Research, 7(2), 70-81.

Ko, H.-L., Wang, Y.-T., Chiu, T.-S., Lee, M.-A., Leu, M.-Y., Chang, K.-Z., Chen, W.-Y., \& Shao, K.-T. (2013). Evaluating the accuracy of morphological identification of larval fishes by applying DNA barcoding. PLOS ONE, 8(1), e53451. https://doi.org/10.1371/journal.pone.0053451

Kwun, H.J. (2018). Species identification of juvenile fishes of the genus Pseudoblennius using mitochondrial DNA barcoding. Mitochondrial DNA Part B, 3(1), 405-408. https://doi.org/10.1080/23802359.2018.1456982

Meusnier, I., Singer, G.A.C., Landry, J.-F., Hickey, D.A., Hebert, P.D.N., \& Hajibabaei, M. (2008). A universal DNA minibarcode for biodiversity analysis. BMC Genomics, 9, 214. https://doi.org/10.1186/1471-2164-9-214

Nelson, J.S., Grande, T.C., \& Wilson, M.V.H. (2016). Fishes of the world. New Jersey, Canada, John Wiley \& Sons Inc., $707 \mathrm{pp}$.

Ngamniyom, A. (2012). Thai ricefish: a potential bio-indicator species for monitoring freshwater environmental pollutions. Srinakharinwirot Science Journal, 28(1), $207-$ 218.

Overdyk, L.M., Holm, E., Crawford, S.S., \& Hanner, R.H. (2016). Increased taxonomic resolution of Laurentian Great Lakes ichthyoplankton through DNA barcoding: a case study comparison against visual identification of larval fishes from Stokes Bay, Lake Huron. Journal of Great Lakes Research, 42(4), 812-818. https://doi.org/10.1016/j.jglr.2016.05.011

Pegg, G.G., Sinclair, B., Briskey, L., \& Aspden, W.J. (2006). MtDNA barcode identification of fish larvae in the southern Great Barrier Reef, Australia. Scientia Marina, 70(S2), 7-12.

Pramanik, M.M.H., Hasan, M.M., Bisshas, S., Hossain, A.B.M.A., \& Biswas, T.K. (2017). Fish biodiversity and their present conservation status in the Meghna River of Bangladesh. International Journal of Fisheries and Aquatic Studies, 5(1), 446-455.

Sambrook, J., \& Russell, D.W. (2001). Molecular cloning: a laboratory manual. New York, United States of America, Cold Spring Harbor Laboratory Press., 2100 pp.

Sarma, K.J., \& Mankodi, P.C. (2017). Deciphering identification of inland fishes of Gujarat using DNA barcoding. Turkish Journal of Fisheries and Aquatic Sciences, 17(5), 10551060. http://doi.org/10.4194/1303-2712-v17_5_22

Suvarnaraksha, A. (2015). Ichthyology. Chiang Mai, Thailand, Maejo University Press., 458 pp. 
Tamura, K., Dudley, J., Nei, M., \& Kumar, S. (2007). MEGA4: molecular evolutionary genetics analysis (MEGA) software version 4.0. Molecular Biology and Evolution, 24(8),

1596-1599. https://doi.org/10.1093/molbev/msm092

Termvidchakorn, A. (2003). Freshwater fish larvae. Bangkok, Thailand, P.A. Living Co., Ltd., 200 pp.

Termvidchakorn, A., Vidthayanon, C., Getpetch, Y., Sorrak, P., \& Paradonpanichakul, P. (2003). Alien aquatic species in Thailand. Retrieved from http://www.fisheries.go.th/ifcenter/web2/images/pdf/alien.pdf

Thai Baan Research. (2006). Thai Baan (villagers') research at Chiang Khong, the Mekong River. Retrieved from http://www.livingriversiam.org/4rivertran/4mk/mek_fisk_book.pdf

Thompson, J.D., Higgins, D.G., \& Gibson, T.J. (1994). Clustal W: improving the sensitivity of progressive multiple sequence alignment through sequence weighting, position-specific gap penalties and weight matrix choice. Nucleic Acids Research, 22, 4673-4680. https://doi.org/10.1093/nar/22.22.4673

Valunpion, S., \& Suvarnaraksha, A. (2013). Fish species diversity in the Ing River. Khon Kaen Agriculture Journal, 41(Suppl. 1), 116-122.

Ward, R.D., Zemlak, T.S., Innes, B.H., Last, P.R., \& Hebert, P.D.N. (2005). DNA barcoding Australia's fish species. Philosophical Transactions of the Royal Society of London. Series B, Biological sciences, 360, 1847-1857. https://doi.org/10.1098/rstb.2005.1716

Wong, E.H.-K., \& Hanner, R.H. (2008). DNA barcoding detects market substitution in North American seafood. Food Research International, 41(8), 828-837. https://doi.org/10.1016/j.foodres.2008.07.005 